Jurnal Pengabdian Multidisiplin

\title{
Pemberdayaan Kelompok Tani Wanita Mandiri Dalam Meningkatkan Produksi Tanaman Cabai Varietas Nirmala-F1 Melalui Penerapan Teknologi MPHP dan BioBoost
}

\author{
Ernest Hanny Sakul ${ }^{1}$, Philotheus Erwin Alex Tuerah ${ }^{2}$, Jacklin Stella Salome Manoppo ${ }^{3}$ \\ ${ }^{1,3)}$ Jurusan Biologi, Fakultas Matematika dan Ilmu Pengetahuan Alam \\ Universitas Negeri Manado \\ 2)Jurusan Matematika, Fakultas Matematika dan Ilmu Pengetahuan Alam \\ Universitas Negeri Manado \\ *Penulis Korespondensi, Ernest Hanny Sakul,Jurusan Biologi FMIPA Universtas Negeri Manado 95600 \\ Email : ernesthannysakul@unima.ac.id
}

\begin{abstract}
ABSTRAK
Teknologi Mulsa Plastik Hitam Perak (MPHP) dan BioBoost adalah teknologi yang ramah lingkungan dan mampu meningkatkan produktifitas lahan pertanian sehingga hasil pertanian akan meningkat baik mutu maupun jumlah hasil panennya. Pemanfaatan Bio-Boost sebagai pupuk organik yang mengandung mikroorganisme tanah yang unggul, diaplikasikan untuk meningkatkan kesuburan tanah sebagai hasil proses biokimia tanah dalam budidaya dan peningkatan produksi tanaman cabai varietas nirmala F-1. Hasil pengamatan dan survey di lapangan khususnya di Desa Kembuan Kecamatan Tondano Utara Kabupaten Minahasa banyak ditemukan lahan/ladang atau bekas sawah yang sudah tidak diefektifkan lagi oleh petani pemilik, sehingga menjadi lahan tidur dan hanya menjadi tempat menggembalakan hewan ternak seperti sapi dan kuda. Selain itu juga, limbah organik yang dapat ditemukan di Desa Kembuan adalah limbah hasil peternakan ayam berupa kotoran ayam, yang bila tidak dikelola dengan baik akan berpotensi mencemari lingkungan. Potensi pemanfaatan lahan tidur dan limbah organik di pedesaan merupakan sebuah peluang usaha untuk meningkatkan kesejahteraan kelompok tani. Berdasarkan hal tersebut di atas, maka dilaksanakanlah Program Kemitraan Masyarakat Kelompok Tani Wanita Mandiri Desa Kembuan Kecamatan Tondano Utara Kabupaten Minahasa Propinsi Sulawesi Utara. Kebutuhan aplikasi teknologi pertanian yang diperlukan oleh kelompok tani ini antara lain adalah teknologi Bio-Boost dan Effective Microorganism (EM4) sebagai agen hayati yang mempercepat proses dekomposisi limbah kotoran ayam menjadi pupuk organik berkualitas, dikombinasikan dengan teknologi mulsa plastik hitam perak dan pengendalian hama menggunakan bioinsektisida, ternyata mampu memberikan hasil yang baik dalam budidaya tanaman cabai rawit varietas nirmala F-1. Hasil panen perdana yang diperoleh kelompok tani ini yaitu cabai rawit varietas nirmala yang memiliki karakteristik morfologi buah lancip, dengan ukuran 4 x 0,8 $\mathrm{cm}$, pedas, warna merah mengkilap dan dapat mulai dipanen pada umur 82-85 hari setelah tanam (HST), rata-rata berat buah cabai per tanaman adalah $0,75-1,0 \mathrm{~kg}$ per tanaman, dengan bobot per buah berkisar 2 - 3 gram dan memiliki potensi hasil $8-10$ ton/ha.
\end{abstract}

Kata kunci : Lahan tidur, Cabai Nirmala F-1, Teknologi MPHP, Bioboost

\section{PENDAHULUAN}

\section{Analisis Situasi}

Desa Kembuan adalah salah satu desa berstatus definitif yang berada di wilayah Kecamatan Tondano Utara Kabupaten Minahasa, Sulawesi Utara. Desa ini boleh di kata berada di pinggiran ibukota Kabupaten Minahasa yaitu
Tondano. Letak geografisnya yang tidak begitu jauh dari pusat kota namun berada dekat dengan ujung perbatasan Kabupaten membuat desa ini tidak begitu terganggu dengan ramainya hirukpikuk suasana kota. Namun tidaklah sulit akses untuk menuju pusat kota Tondano yang berjarak 


\section{Jurnal Pengabdian Multidisiplin}

kurang lebih 1 kilometer saja. Suasana yang tenang tentu amat menarik karena desa ini pun di kelilingi oleh lokasi perkebunan dan lahan pertanian warga setempat. Di wilayah sebelah selatan desa ini memiliki perkebunan tanaman Seledri yang luas dan Stadion olahraga Maesa. Di sebelah utara dan barat hamparan perkebunan penduduk dan perbukitan menghiasi panoramanya. Sementara di bagian timur kita akan menemukan sungai Tondano yang juga menjadi salah satu sumber penunjang kehidupan warga, baik untuk cuci pakaian, mandi, ataupun tambak ikan.

Desa Kembuan mulanya berasal dari desa Tonsea Lama yang dimekarkan dengan nama desa Kembuan yang berarti "Mata air". Pada tahun 1985-1986 desa ini menjadi desa persiapan setelah pada 21 Februari 1985 secara resmi menjadi desa Kembuan yang terpisah dari desanya semula desa Tonsea lama. Pada tahun 1987-1989 berubah status menjadi desa definitif. Desa ini berbatasan dengan desa Tanggari di sebelah utara, dengan desa Tonsea Lama di sebelah timur, dengan Luaan dan Wewelen di sebelah selatan, dan dengan Rurukan, Kumelembuai, Sasaran, dan Kembuan Satu di sebelah Barat. Sebagain besar dari area desa Kembuan memang dipenuhi dengan hamparan perkebunan. Luas wilayahnya adalah 1039.8 ha dengan potensi pertanian yaitu tanaman Kelapa 600 ha, Cengkih 2000 ha, Jagung 1000 ha, Kedelai 250 ha, Kacang tanah 250 ha, Ubi jalar 300 ha, Singkong 350 ha, dan berbagai sayuran 320 ha. Dalam sekali panen tanaman hasil cengkihnya bisa mencapai 3 ton, kedelai 1 ton, kacang tanah 1 ton, ubi jalar 2 ton, Singkong 1 ton, dan sayuran 1 ton. Adanya kelompok tani aktif dan produktif yang ada di desa pun sangat menunjang produksi pertanian dan perekonomian petani dan buruh tani di desa.

Potensi penduduknya sebanyak 661 kepala keluarga atau sekitar 1138 laki-laki dan 1096 perempuan dengan total jumlah 2234 warga. Warga berusai produktif dengan kisaran usia dari
20-59 tahun berkisar 921 jiwa. Keadaan pendidikan warga yang tamatan SMA berjumlah 544 jiwa dan bergelar Sarjana berjumlah 80 jiwa.

Pekerjaan warga Kembuan banyak dipengaruhi oleh lokasi geografisnya yang luas akan area perkebunan, sekitar 124 warga tercatat sebagai petani akitf dalam arti tidak memiliki pekerjaan lain selain fokus sebagai petani. Jumlah tersebut kedua terbanyak setelah 197 warga lainnya yang memilih usaha wiraswasta dan pegawai swasta. Berturut-turut berikutnya adalah 59 orang berprofesi sebagai buruh, 58 orang sebagai tukang, 50 orang sebagai sopir, 44 orang pedagang, 42 orang sebagai PNS, dan terakhir ada 17 orang sebagai TNI/Polri. Keadaan populasi keagamaan desa Kembuan cukup beragam, tercatat ada 3 agama yang dianut warga Kembuan yaitu Katolik 60 jiwa, Islam 12 jiwa, dan Kristen Protestan sebagai agama mayoritas yang terbagai dalam 4 golongan gereja. GMIM dengan jumlah jemaat terbesar yaitu 1298 jiwa, di susul GSJA dengan 87 jiwa, GPDI 71 jiwa, dan GMAHK 25 jiwa.

Fasilitas umum di desa Kembuan tergolong amat lengkap dibandingkan desa-desa yang lain, kita dapat dengan mudah menemukan fasilitas pendidikan dari tingkat TK hingga SMA sederajat. Ada dua buah TK di Kembuan yaitu TK GMIM Kembuan dan TK Pembina. Selanjutnya ada SD Inpres Kembuan, SMP 6 Tondano, SMA 3 Tondano dan SMK 1 Tondano.

Pelayanan kesehatan Puskesmas bertempat di ibukota Kecamatan yaitu desa Tonsea Lama yang hanya berjarak tidak sampai 1 kilometer. Tenaga kesehatan di Kembuan memiliki seorang dokter dan seorang bidan. Pelayanan kesehatan khusus di desa diadakan setiap bulan sekali oleh kunjungan tim dinas kesehatan Kecamatan. Adapun untuk fasilitas air bersih, warga memiliki 37 unit air ledeng/PDAM, sumur sebanyak 98 unit, dan leher angsa sebanyak 421 unit. Untuk sarana olahraga di desa Kembuan terdapat sebuah lapangan sepakbola, sebuah lapangan Badminton dan 3 buah lapangan bola voli. Sarana olahraga 


\section{Jurnal Pengabdian Multidisiplin}

tersebut terbukti sangat membantu meningkatkan minat dan prestasi warga setempat sebab desa Kembuan beberap kali meraih prestasi dalam cabang-cabang olahraga tersebut.

Desa Kembuan Kecamatan Tondano Utara, terdapat kelompok tani yang bergerak di bidang tanaman hortikultura dan kelompok ternak yang bergerak dalam usaha ternak itik disamping usaha ternak yang lain dan usaha tani padi sawah. Akhir-akhir ini sering terdengar keluhan dari petani karena hasil panennya terus menurun dari tahun ke tahun. Keadaan ini terjadi karena tingkat kesuburan dan bahan organik tanah yang mengalami penurunan, sehingga kemampuan tanah untuk mendukung ketersediaan air, hara dan kehidupan mikroorganisme yang dibutuhkan tanaman terus mengalami penurunan.

Struktur keanggotaan kelompok tani wanita mandiri desa Kembuan terdiri dari ketua, sekertaris, bendahara dan anggota seperti yang tertera pada Tabel 1.

\begin{tabular}{|c|c|c|c|}
\hline \multicolumn{4}{|c|}{ Tabel.1. Struktur Keanggotaan Kelompok } \\
Tani Wanita Mandiri Desa Kembuan
\end{tabular}

\section{b. Permasalahan Mitra}

Hasil pengamatan dan survey di lapangan khususnya di Desa Kembuan Kecamatan Tondano Utara Kabupaten Minahasa banyak ditemukan lahan/ladang atau bekas sawah yang sudah tidak diefektifkan lagi oleh petani pemilik, sehingga menjadi lahan tidur dan hanya menjadi tempat mengikat atau menggembalakan hewan ternak seperti sapi dan kuda. Selain itu juga, limbah organik yang dapat ditemukan di Desa Kembuan adalah limbah hasil peternakan ayam berupa kotoran ayam, yang bila tidak dikelola dengan baik akan berpotensi mencemari lingkungan. Potensi pemanfaatan lahan tidur dan limbah organik di pedesaan merupakan sebuah peluang usaha untuk meningkatkan kesejahteraan kelompok tani.

Selain itu juga mekanisme cara bercocok tanam hortikultura yang masih menggunaan pupuk buatan dalam jumlah banyak akan menimbulkan masalah bagi kelompok tani terutama efek residu pupuk kimiawi yang membahayakan kesehatan konsumen pengguna cabai.

Berdasarkan hal tersebut di atas, maka dilaksanakanlah Program Kemitraan Masyarakat Kelompok Tani Wanita Mandiri Desa Kembuan Kecamatan Tondano Utara Kabupaten Minahasa Propinsi Sulawesi Utara.

Kebutuhan aplikasi teknologi pertanian yang diperlukan oleh kelompok tani ini antara lain adalah teknologi Bio-Boost dan Effective Microorganism (EM4) sebagai agen hayati yang mempercepat proses dekomposisi limbah kotoran ayam menjadi pupuk organik berkualitas, dikombinasikan dengan teknologi mulsa plastik hitam perak dan pengendalian hama menggunakan bioinsektisida, diharapkan dapat memberikan hasil yang baik dalam budidaya tanaman cabai rawit varietas nirmala F-1.

\section{Tujuan dan Manfaat Kegiatan Tujuan Kegiatan}

Sesuai dengan rencana kegiatan, maka tujuan yang menjadi target dalam pelaksanaan kegiatan program kemitraan masyarakat ini adalah :

a. Melatih kelompok tan untuk dapat meningkatkan kuantitas dan kualitas produk cabai varietas nirmala.

b. Membimbing dan melatih para petani untuk dapat memproduksi sendiri pupuk organik hasil fermentasi limbah kotoran ayam dengan menggunakan Effective Microorganism (EM4) (Musnamar, 2016).

c. Melatih para petani agar terampil dan mampu mengaplikasikan penggunaan pupuk organik 
Jurnal Pengabdian Multidisiplin

BioBoost dalam meningkatkan produktifitas tanaman cabai.

d. Membimbing dan melatih kelompok tani, dalam menggunakan Mulsa Plastik Hitam Perak (MPHP).

e. Melatih dan membimbing proses pembuatan bioinsektisida berbahan dasar tumbuhan pangi (Sakul, et al.,2012)

\section{Manfaat Kegiatan}

a. Kegiatan ini diharapkan dapat memberikan manfaat bagi kelompok tani sehingga mampu mengaplikasikan penggunaan pupuk organik BioBoost yang dikombinasikan dengan pupuk organik hasil fermentasi limbah kotoran ayam yang menggunakan agen hayati EM4 dan pemanfaatan MPHP, sehingga mampu meningkatkan hasil panen tanaman cabai rawit varietas Nirmala F-1.

b. Bagi UNIMA, kegiatan ini adalah upaya perwujudan misi perguruan tinggi, terutama mewujudkan salah satu dari Tri Dharma Perguruan Tinggi, yaitu dharma pengabdian pada masyarakat.

\section{Solusi yang ditawarkan}

Belajar dari pengalaman dan informasi yang telah diperoleh dari masyarakat desa (kelompok sasaran) yaitu kelompok tani wanita mandiri Desa Kembuan Kecamatan Tondano Utara, ternyata kelompok tani membutuhkan program pelatihan guna meningkatkan pengetahuan dan keterampilan mereka dalam aplikasi penggunaan pupuk organik BioBoost dalam meningkatkan produktifitas tanaman cabai rawit sehingga dapat meningkatkan penghasilan dan kesejahteraan bagi petani dan keluarganya. Bersamaan dengan pelaksanaan demplot tersebut, dilaksanakan juga penyuluhan lapangan dan pendampingan teknis budidaya cabai dengan varietas unggulan (varietas nirmala), seperti teknologi budidaya yang lebih ramah lingkungan berupa pembuatan kompos padat melalui teknik fermentasi dengan menggunakan agen hayati EM4 pada limbah kotoran ayam, pelatihan teknik pemasangan mulsa plastik hitam perak (MPHP) dengan baik dan benar, serta pelatihan pembuatan pestisida organik (biopestisida) juga dikembangkan dalam pelatihan ini (Sakul dan Nangoy, 2017)

\section{METODE PELAKSANAAN}

Adapun beberapa metode yang digunakan dalam kegiatan ini adalah :

a) Metode pelatihan kepada kelompok tani dalam bentuk presentasi pelatihan tentang komponen pupuk organik BioBoost dan cara mengaplikasikannya pada tanaman hortikultura khususnya tanaman cabai rawit.

Pengenalan awal tentang pupuk organik BioBoost kepada kelompok tani, kemudian dijelaskan komposisi komponen penyusun pupuk cair tersebut dan fungsi utama pemberian perlakuan pupuk organik BioBoost tersebut. Bersamaan dengan hal tersebut diatas, diberikan juga informasi tentang benih cabai rawit varietas Nirmala F1 yang digunakan, perihal kualitas benih, daya kecambah, jumlah maksimal benih di dalam paket benih yang akan digunakan.

Juga dilakukan sharing pengalaman dari sesama petani yang masih menggunakan metode lama dalam bercocok tanam cabai, kemudian saling menginformasikan hal/masalah utama dalam meningkatkan produksi tanaman cabai (Sakul et al.,2019)

b) Metode demonstrasi dan unjuk kerja secara langsung dalam menggunakan pupuk organik BioBoost pada cabai. Diawali dengan kerja bersama di areal kebun yang akan ditanami cabai, dimulai dengan proses pembajakan dan pembongkaran tanah, kemudian diratakan dengan hand traktor, hingga lokasi tanam siap untuk ditanami, termasuk didalamnya proses pembuatan bedengan secara manual. 
Jurnal Pengabdian Multidisiplin

Kemudian digunakan bibit cabai yang baik, guna mendapatkan produksi yang maksimal adapun benih yang digunakan adalah jenis cabai rawit Nirmala , dengan daya kecambah 99\% dan viabilitas benih yang sangat baik (Manoppo et.al., 2018b).

c) Memberikan pelatihan pembuatan pupuk organik dengan memanfaatkan mikroorganisme (EM-4) sebagai upaya untuk mempercepat proses dekomposisi limbah organik menjadi pupuk organik, guna meningkatkan produksi dan kualitas tanaman cabai, juga penggunaan teknik bercocok tanam cabai dengan bantuan mulsa plastik hitam perak (Musnamar, 2016).

d) Memberikan pelatihan pembuatan pestisida organik berbahan dasar tanaman lokal yang berpotensi untuk dijadikan bahan baku pestisida organik dalam mengatasi hama tanaman cabai (Manoppo, 2017; Sakul, 2017).

e) Metode aplikasi di lapangan secara langsung dengan menanam benih cabai yang telah selesai disemai, memeliharanya dan memberikan perlakuan konsentrasi pupuk organik BioBoost pada tanaman cabai yang baik dan benar.

f) Penanganan pasca panen dan teknik pemasaran produk yang berkualitas guna meningkatkan income petani.

\section{HASIL DAN LUARAN YANG DICAPAI Pelaksanaan Program}

Kegiatan program kemitraan masyarakat dilaksanakan di Desa Kembuan Kecamatan Tondano Utara Kabupaten Minahasa. Yang menjadi sasaran pelaksanaan kegiatan program kemitraan ini adalah para petani yang tergabung dalam kelompok tani wanita mandiri yang berjumlah 5 orang dan aktif bercocok tanam sampai saat ini.

Gambaran IPTEK yang telah dilaksanakan pada mitra kelompok tani wanita mandiri Desa Kembuan Kecamatan Tondano Utara adalah :
1. Pengelolaan tanah pada lahan yang akan dijadikan tempat penanaman bibit cabai nirmala, dilakukan dengan membuat bedengan yang memiliki ukuran panjang 15 meter, lebar 1,5 meter, jarak antar bedengan $70 \mathrm{~cm}$ dan tinggi bedengan 30-40 cm, yang disertai pemupukan dasar berupa penambahan bahan organik hasil fermentasi seperti pupuk bokashi EM4. Kemudian lahan disiapkan 10 hari sebelum masa tanam, dengan tetap menggunakan kombinasi $70 \%$ pupuk organik dan 30\% pupuk dasar jenis Urea, ZA, TSP, SP-36 dan KCL (Manoppo et.al.,2018a).

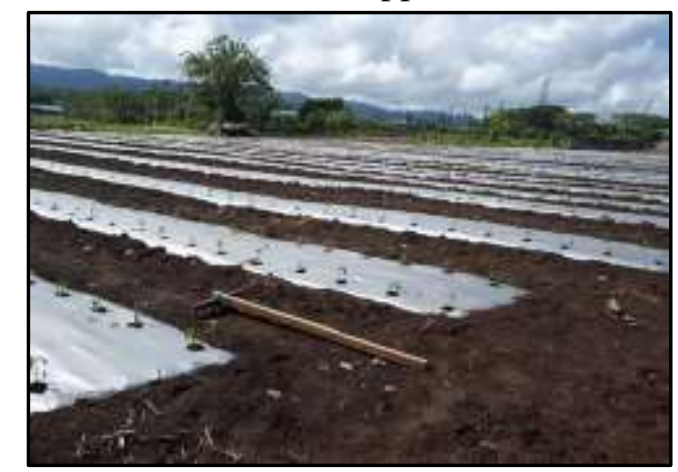

Gambar1. Demplot Lahan Tanaman Cabai PKM Kelompok Tani Wanita Mandiri Desa Kembuan Kecamatan Tondano Utara

2. Teknik penyemaian benih cabai rawit varietas nirmala F1 yang baik dan benar dengan menggunakan tray bibit maupun plastik semai dan campuran media semai jenis cocopeat. Benih dipelihara di screen house sederhana atau sungkup (Santika, 2017).

3. Teknik pemasangan mulsa plastik hitam perak (MPHP), cara mengencangkan mulsa pada bedengan dan cara membuat lubang tempat menanam bibit pada mulsa. Juga teknik memasang ajir atau lanjaran (bambu penyokong). 
Jurnal Pengabdian Multidisiplin

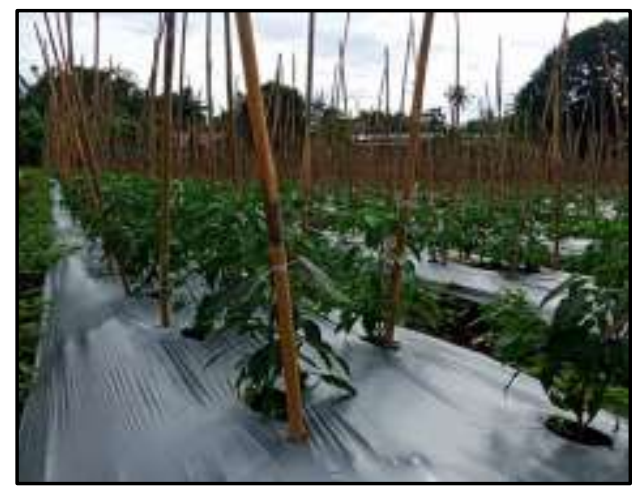

Gambar 2. Pemeliharaan Bibit Cabai Varietas Nirmala dengan MPHP

4. Teknik pemeliharaan lanjutan untuk tanaman cabai sekaligus pemupukan dengan menggunakan pupuk organik BioBoost dalam meningkatkan kualitas fase vegetatif dan generatif.

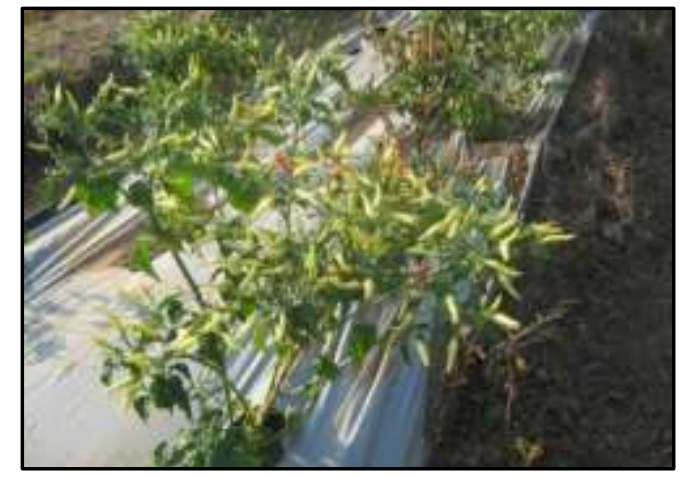

Gambar 3. Tampilan Cabai Varretas Nirmala

5. Teknik pengendalian hama terpadu dengan membuat bioinsektisida berbahan dasar tumbuhan pangi (Manoppo dan Nangoy, 2017).

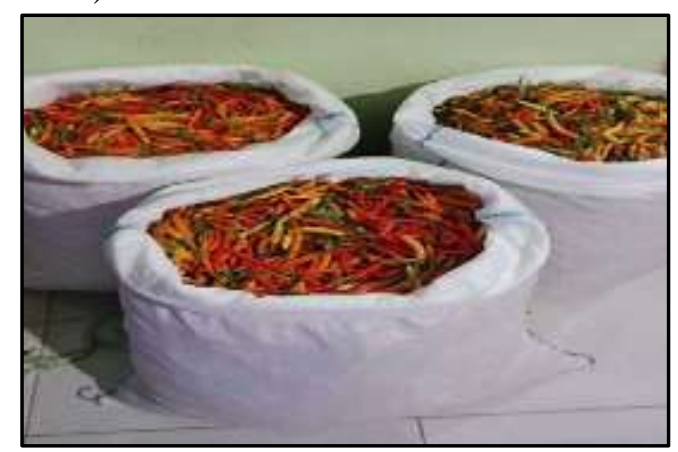

Gambar 4. Cabai Varietas Nirmala Panen Perdana

6. Penanganan pasca panen tanaman cabai varietas nirmala

\section{Monitoring dan Evaluasi}

Monitoring dilaksanakan selama pelaksanaan kegiatan. Dilakukan minimal satu kali seminggu dengan memeriksa laporan kemajuan harian dari kelompok tani tersebut.

Kegiatan monitoring turut dihadiri oleh ketua kelompok tani dan pimpinan/pemerintah desa Kembuan dan perwakilan LPPM UNIMA.

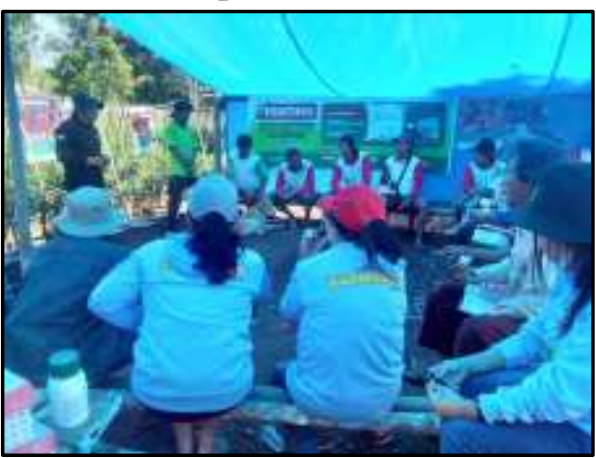

Gambar 5. Diskusi dalam rangka Monitoring dan Evaluasi Program

Evaluasi keterlaksanaan program kemitraan masyarakat dilakukan 3 kali yaitu evaluasi pada awal, pertengahan dan akhir pelaksanaan program. Metode evaluasi mencakup diskusi dan analisis hasil panen akhir, metode pemeliharaan dan hambatan yang diperoleh selama PKM berlangsung.

\section{KESIMPULAN DAN SARAN \\ Kesimpulan}

Program Kemitraan Masyarakat Pada Kelompok Tani Cabai Desa Kembuan Kecamatan Tondano Utara Kabupaten Minahasa, telah memberikan dampak positif dalam peningkatan kualitas income finansial dari setiap anggota kelompok tani wanita mandiri.

Petani dapat mengaplikasikan metode cara bercocok tanam yang baik dan benar, dalam meningkatkan hasil panen cabai dari segi kuantitas dan kualitas hasil cabai, seperti teknik membuat pupuk organik EM4, aplikasi pupuk organik BioBoost, penggunaan Mulsa Plastik 
Jurnal Pengabdian Multidisiplin

Hitam Peraka (MPHP) dan pembuatan bioinsektisida berbasis tumbuhan Pangi.

Hasil panen perdana yang diperoleh kelompok tani ini yaitu cabai rawit varietas nirmala yang memiliki karakteristik morfologi buah lancip, dengan ukuran 4 x $0,8 \mathrm{~cm}$, pedas, warna merah mengkilap dan dapat mulai dipanen pada umur 82-85 hari setelah tanam (HST), ratarata berat buah cabai per tanaman adalah $0,75-$ $1,0 \mathrm{~kg}$ per tanaman, dengan bobot per buah berkisar $2-3$ gram dan memiliki potensi hasil 8 -10 ton/ha.

\section{Saran}

Untuk meningkatkan produksi cabai rawit varietas nirmala $\mathrm{F} 1$ dalam menunjang ketahanan dan kemandirian pangan berbasis pertanian organik, salah satu strategi yaitu penggunaan Mulsa Plastik Hitam Perak, Pupuk Organik BioBoost, Pupuk Organik Hasil Fermentasi EM4 dan Bioinsektisida.

\section{UCAPAN TERIMA KASIH}

Terima Kasih disampaikan kepada Rektor Universitas Negeri Manado dan Ketua Lembaga Penelitian dan Pengabdian Masyarakat dan seluruh staf LPPM Universitas Negeri Manado yang telah memberikan bantuan dana melalui Skim PKM Sumber Dana PNBP UNIMA 2019.

Tak lupa juga terima kasih kepada Kelompok Tani Wanita Mandiri dan Hukum Tua Desa Kembuan Kecamatan Tondano Utara Kabupaten Minahasa.

\section{DAFTAR PUSTAKA}

Manoppo,J.S.S., dan E. H. Sakul dan Marlina Karundeng., 2018a. Penggunaan Pupuk Organik Untuk Meningkatkan Hasil Tanaman Cabai Kelompok Tani di Kabupaten Minahasa. Jurnal Dedikasi Lembaga Pengabdian Masyarakat Universitas Negeri Makassar ISSN: 02510891. Vol 20. No.1 Oktober 2018.
Manoppo,J.S.S. 2017. Potential Extracts of Pangium edule Reinw and Derris elliptica Wallich as Botanical Molluscicides for Management of Golden Apple Snail Pomacea canaliculata Lamarck. Agrotech Journal. Universitas Sembilan Belas Nopember Kolaka. 2 (2).

Manoppo, J. S. S., dan Wiesye M.S. Nangoy., 2017. Potensi Bioisektisida Dari Ekstrak Biji Dan Ekstrak Kulit Batang Tumbuhan Pangi (Pangium edule Reinw.) Dalam Meningkatkan Mortalitas "Gai Gantung” Plutella xylostella L. Departemen Biologi, Fakultas Matematika Dan Ilmu Pengetahuan Alam Universi.as Negeri Manado, dalam Proceeding Seminar Nasional Biologi XXIV 2017. "Penelitian, Bioprospeksi dan Pemanfaatan Berkelanjutan dari Keanekaragaman Hayati”. Perhimpunan Biologi Indonesia dan Universitas Sam Ratulangi Manado

Manoppo, J.S.S. dan E. H. Sakul dan Marlina Karundeng., 2018b. PKM Kelompok Tani Cabai Di Desa Paslaten Kecamatan Remboken Kabupaten Minahasa Propinsi Sulawesi Utara. Jurnal Pengabdian Kepada Masyarakat, DAYA SAINS. Lembaga Penelitian dan Pengabdian Pada Masyarakat, Universitas Negeri Manado. 1(1).

Musnamar, E. Ismawati. 2016. Pupuk Organik Cair dan Padat, Pembuatan dan Aplikasi. Penebar Swadaya, Jakarta.

Santika, A. 2017. Agribisnis Cabai. Penebar Swadaya Jakarta.

Sakul, E.H., R. A. Mege dan J. S. S. Manoppo, 2019. Budidaya Tanaman Hortikultura Memanfaatkan Lahan Pekarangan di Bunaken Manado. Jurnal Dedikasi Lembaga Pengabdian Masyarakat Universitas Negeri Makassar. 21(1).

Sakul, E.H., 2017. Impact of Botanical Insecticides Derived From Pangium edule Reinw And Annona muricata L. Seed 
Jurnal Pengabdian Multidisiplin

Extracts On The "Gay Gantung" Diamondback Moth, Plutella xylostella $L$. Agrotech Journal. Universitas Sembilan Belas Nopember Kolaka 2(2).

Sakul, E.H., J. S .S. Manoppo, D. Taroreh, R. Gerungan dan S.Gugule., 2012. Pengendalian Hama Kumbang "Logong” (Sitophylus oryzae L.) Dengan Menggunakan Ekstrak Biji Pangi (Pangium edule Reinw.). Control Of Beetle Pest Logong (Sitophylus Oryzae L.) Utilized Pangi (Pangium edule Reinw.) Seed Extract. Jurnal ilmiah Eugenia 18(3). Sakul, E.H, dan W. M.S. Nangoy., 2017. Optimalisasi Pembuatan Pestisida Organik Dalam Meningkatkan Produksi Tanaman Sawi dan Pak Choy Pada Kelompok Tani Maleosan Kabupaten Minahasa. Departemen Biologi, Fakultas Matematika Dan Ilmu Pengetahuan Alam -Universitas Negeri Manado, dalam Proceeding Seminar Nasional Biologi XXIV 2017. "Penelitian, Bioprospeksi dan Pemanfaatan Berkelanjutan dari Keanekaragaman Hayati”. Perhimpunan Biologi Indonesia dan Universitas Sam Ratulangi Manado. 